\title{
Teaching's Characteristics: Novices Talk about Teaching
}

\author{
Ditza Maskit \\ Gordon College of Education, Haifa, Israel \\ Email: ditzamaskit@gmail.com \\ Received 10 July 2014; revised 10 August 2014; accepted 17 August 2014 \\ Copyright (C) 2014 by author and Scientific Research Publishing Inc. \\ This work is licensed under the Creative Commons Attribution International License (CC BY). \\ http://creativecommons.org/licenses/by/4.0/ \\ c) (i) Open Access
}

\begin{abstract}
The purpose of this study is to explore common themes emerging from lived experiences of novices' teachers regarding the main characteristics of the teaching profession as they surface from their personal diaries kept in the first year of their work. Findings from the diaries indicate that teaching was described, as an experiential profession and unique for each teacher. Other characteristics are direct towards the contextually of the profession, its complexity and its pluralism. Relating to these teaching' characteristics before the induction phase, during the clinical training may reduce the induction' shock, and even reduce novices' dropout from teaching.
\end{abstract}

\section{Keywords}

Novices, Teaching as a Profession, Written Diaries, Teaching's Characteristics

\section{Theoretical Background}

\subsection{Entry into Teaching}

The first year of teaching-being “on the job” is an important period in the professional development cycle of teachers.

Recently, researchers have placed special emphasis on the induction stage in teaching as regard by novices ${ }^{1}$ themselves. This stage has been describes as one of the most challenging and demanding stage in teachers' professional life (Fantilli \& MCDougall, 2009; Ulvik, Smith, \& Helleve, 2009). Studies indicate that teaching is perceived as an influential profession even before training starts (Lortie, 1975; Weinstein, 1990), and in the course of training (Britzman, 1991; Kelchtermans \& Ballet, 2002; O’Brien \& Schillaci, 2002; Stoeber \& Rennert, 2008). Dominant causes that are enrolled in the decision to become a teacher and to enter the education

\footnotetext{
${ }^{1}$ The term "novices” refers to new teachers during their first year of teaching in this study.
} 
profession focus in the role of the teacher-as perceived in student teachers view (Anhorn, 2008) and the love for continuous learning and teaching (Culross, 2007). Other motivations and perceptions about teaching such as teaching ability; social influences; time for family; prior teaching and learning experiences; and enhance social equity were also mentioned in the literature (Fokkens-Bruinsma \& Canrinus, 2012). However, the difference between reality, and what novices perceived the teaching profession is becoming one of the difficulties that novices face while entering into the classroom (Melnick \& Meister, 2008). Novices also experience disparities between their expectations of their role as a teacher and actual realities faced during their first year (Inman \& Marlow, 2004). Those differences between "being a student teacher" before the entrance into teaching and "being a novice" while teaching present a challenge "in terms of developing teacher education and supporting in-service teachers in their ongoing professional development” (Mäkinen, 2013: p. 52).

Entering into teaching is marked by rapid exposure to teaching complexity, the broad spectrum of its roles, the great responsibility and commitment it involves, and variety of people engaged in it. Studies regarding the induction phase reveal that this stage has far-reaching effects on teachers' career development (Bickmore \& Bicmore, 2010; Cochran-Smith, 2004a; Gaudelli \& Ousley, 2009). In addition, it has been specify that the actual entry into the profession is significant in developing a perception of teaching (Cochran-Smith, 2004b) and in forming attitudes and perceptions regarding the characteristics of the profession.

Research concerning the entrance into the teaching arena focuses on various facets. Among them are: The difficulties of novices (i.e. Maskit, 2013; Hobson, Malderez, Kerr, Tracey, Tomlinson, \& Roper, 2005; Kyriacou \& Kune, 2007; cycles of novices' support-mentoring support procedures and promoting facilities available to novices (i.e. Bullough \& Draper, 2004; Ingersoll \& Kralik, 2004; Norman \& Feiman-Nemser, 2005; Rippon \& Martin, 2006); the effect of the organizational culture of the host educational system including its environment, the role and behavior of the school principal (i.e. Kelchtermans \& Ballet, 2002; Kurland, 2010). Findings from those studies indicate that the first year of teaching exposes novices to the essence of the teaching work and its complexity, the broad spectrum of teaching roles, the great responsibility and commitment it involves, and the variety of people engaged in this profession.

\subsection{Entry into Teaching in Israel-The Context of the Research}

In Israel, mandatory internship became effective in 2000. All new teachers require to practice a one-year internship (the induction) and to undergo standardized assessment procedures (Ministry of Education, 2004) in order to be accredited with a teaching certificate from the Ministry of Education. During this period, novices have to work at least $1 / 3$ of the statutory hours of a full-time teacher and they are exposing, during their internship year to two cycles of support. Those cycles include a personal mentor from the educational system and a weekly support workshop at one of the teacher education institutions (university or college). After complying successfully with their evaluation and completing all internship duties, novices are awarded a license to practice the teaching profession

In the last decade, much thought and activity has been invested in studying the aspects of the first stages of teachers' career. Programs have developed to improve the educational orientation and support concerning novices' life. Given the above developments and facing the professional path that novices experience during the induction, it becomes important to pinpoint how novices define the landscape of teaching profession and its characteristics while becoming teachers in "real life". The present study focused on this facet trying to explore how novices describe the main characteristics of the teaching profession.

\section{The Research Method}

\subsection{Research's Question}

What are the main characteristics of the teaching profession as they surface from novices' personal diaries?

\subsection{Participants}

Participants were 25 novices, chosen as a purposeful sample (Patton, 2002) to represent the intern population participating in intern support workshops in an optimal manner. The population was drawn from three weekly support workshops operating in three teacher-training institutes. All participants expressed interest and involvement in the writing of their journals. All of them had just finished their training and had been assigned to ele- 
mentary schools as interns. All participants gave their agreement to participate in the study. The participants were assured anonymity and confidentiality.

\subsection{Data Collection}

The research presents an analysis of the novices' reflections as they were recorded in their diaries during their internship year. Personal diaries have been employed as a research tool in previous studies (Maskit, 2013; Gilar, Maria de los Angeles, \& Castejón, 2007; Stoughton, 2007) in which reflective discussion in writing serves as a channel of investigation into the lives of beginning teachers. Moreover, as indicate before, keeping the diary makes it possible to develop critical attitudes; to describe teachers' practical experiences (Maskit \& Dickman, 2006; Gilar et al., 2007; Kitching, Morgan, \& O’Leary, 2009; Leavy, McSorley, \& Boté, 2007; Leshem \& Trafford, 2006); and to attain a bright look at events (Connelly \& Clandinin, 1988), while developing a critical thinking.

The reflective thinking of the novices concerning their work served as a primary source allowing the researcher to gain a "back-stage" view of their experiences and understanding of the teaching world.

As part of their participation in the weekly support workshop, participants were asked to keep an open personal diary. Each intern was asked to send a detailed personal weekly report (a total of 3 - 4 reports for a month) to the mentor of the weekly support workshop by e-mail. The reports described processes they experienced in their teaching work during that week. Novices were not required to relate to any specific subjects, so that the choice of subjects, manner of description, the scope, timing of the events or writing style were left to their decision. In the end of the year and as a final summary of their internship, the novices had to review their diaries, to choose 10 important reports from their diaries (one report for each month of teaching) and to rewrite them as a summary of their induction. The findings of the present research are based on those summaries, including 250 reports selected by the novices themselves.

\subsection{Analysis and Interpretation of Findings}

The current research presents an analysis of novices' echoes as they were detailed in their diaries during their first year of teaching qualitative content analysis was applied to the findings (Patton, 2002), allowing the researcher to infer insights from the content (Clandinin, 1986; Cochran-Smith \& Lytle, 1990; Strauss \& Corbin, 1994).

After analyzing the content, through open coding (Strauss, 1987) several subjects were found to recur with conspicuous frequency. The analysis unit was the "episode", a limited content unit concentrated around a single event or reference that constitutes an independent unit as to subject and content.

The qualitative analysis focused on the portrayals of the main characteristics of the teaching profession that the novices describe in their diaries. Other content categories such as the novices' difficulties, the coping strategies that novices employed to deal with these difficulties, the contribution of the diary's writing, the supportive workshop, were separated from the overall system of data and were not included in the derivation of the findings. Therefore, the findings of this work were based only on some of the categories collected during the research.

\section{Findings}

According to the research question, we identified five central characteristics of the teaching profession, chosen based on the frequency of their occurrence in the diaries. Those teaching's characteristics are as follow: The experiential nature of teaching, the uniqueness of teaching for each teacher, the contextually of the profession, the complexity of teaching and its pluralism. The identified characteristics of the teaching profession are now described by category and illustrated with quotations from the diaries. All names are fictitious.

\subsection{The Experiential Characteristic of Teaching}

All novices indicate in their diaries that teaching is an experiential profession and dynamic. They all mention that experience is a main component of becoming a teacher.

"When my tutor told me that every day I'd learn something new from my own experience, I thought she was just trying to make me feel good. Fact is, though, that in the work itself I suddenly discovered that my knowledge of how to teach was coming from teaching in the classroom. For instance, I understood that the 
best method for my class was to ask questions. Now I try to think of leading questions and feel that I'm making progress". (Yael)

"In the first stages ... I felt so young, new and inexperienced ... I simply lacked this experience. I had to learn through the work itself". (Leor)

"Experience in the field is the best learning ... I came with knowledge of the subject, and then suddenly I saw what it means to be a teacher. All the details seemed clumped together. I had to study the material itself, understand the levels of the pupils. Besides I had to solve the problem of noise, children fighting, plan work sheets, and run between different classes and age groups. The whole experience taught me that experience in the field is really the best way to learn, and in the course of the year I learned on my own in the field”. (Dekla)

"This is a moment of truth, me with the pupils ... I'm alone, without the teacher trainer, without the pedagogy counselor, just me. This is real teaching for real ... and the experience is mine and I have to decide what to do and do it.” (Hila)

"Here in the workshop we learn a lot from the experience of others. But only when I go into the classroom and only when I myself try to teach according to the way I've been taught, only then can I be certain whether it suits me and my pupils. It's a challenge to examine myself through experience ...” (Dana)

"How do I learn? From my own experience. Yesterday, only after I gave the children work sheets and said to turn them over and not read them, and nobody turned the sheets over ... only then did I learn from experience not to give out the work sheets and not ask [the pupils] to turn them over. Had anyone told me, I would have thought it would not happen to me, that if I told them to, the pupils would not turn over the page. But experience taught me differently.” (Shira)

These incidents indicate how new teachers in their entry year recognize that experience is a major characteristic of teaching. Furthermore, novices also sense the force of actual practice as an integral part of learning how to teach. Teaching as an experiential process reinforces novices in their first steps in teaching to try, to practice, to be involved with new methods and new materials, and not to hesitate to experiment, to structure their professional world through such experiments and to turn experimental error into a learning experience.

\subsection{Uniqueness of the Professional}

This characteristic relates to the unique nature of every teacher as a professional. Michal describes how surprised she was to find this out:

"All of a sudden I saw that to be a teacher really means to act in a unique way that's right for me and my abilities. I understood that in fact everything depends on me and what I do in the classroom, which improved my teaching, but also put a heavy burden on me.”

The practical significance of this point illustrate how teachers differ as to the importance they attach to situations that arise in the course of their teaching. Thus, for example Orit describes the cooperative work at her school, during which she discovered how teaching is can be a personal and an individual work:

"I was so happy that the Bible Studies teachers decided to make work sheets for all the classes. I got busy at home and prepared study tasks that seemed to me really interesting and challenging. I even looked up material in the sources. However, when we met, I saw right away that we were not on the same 'wave length'. I thought that the summary of material should be an enrichment of the material itself They suggested tasks quite separate from the biblical text ... Their ideas were different ... They were my team members and I had to accept it. It was hard not to be insulted.”

Oren's diary states his conclusions regarding team teaching:

"There's another teacher for the subject at the school, and we divide the work between us ... As we were planning an exam for the two classes, I noticed that we each taught with different emphases. Suddenly I understood the differences between us, significant differences in teaching style and in transmitting the material. Sometimes we use different methods, each of which stresses different aspects of a concept and caus- 
es it to be understood in an entirely different way."

These quotations show how novices identify the uniqueness of teaching as a main characteristic of teaching. As novices expose their personal interpretations to colleagues' criticism and testing, they become aware that teachers are different one from the other, and that teacher's uniqueness takes place in being a teacher. This may help novices to combine between their own interpretations of teaching situations with those of colleagues, and draw their attention to the complicated processes that bring about professional collaboration. That awareness contributes to novices' professional development as teachers and as staff members.

\subsection{Teaching and Its Context}

The diaries stressed as well the link between teaching processes and the context around, as a characteristic of the profession. Anat tells how she was first exposed to the importance of "knowing the context" and considers this characteristic in her planning. In her diary, she describes how knowing the children's world becomes a central concern in her teaching.

“In the beginning I didn't have much idea of how to stir up interest and motivate the pupils to learn. My friend Yael told me it was a good idea to reward them with stickers. I came into class and told them that whoever took part in the lesson would get a sticker. Then they demanded to see what the stickers were like, because if they were nothing special it was not worth working for them. The climax came when Dana told me 'They're not worth anything. They have no spangles'."

When Anat thought of the stickers as a possible learning stimulus, she did not consider her pupils' expertise in the realm of stickers. The classroom experience gave rise to the insight that context influences teaching, and to summing up the episode thus:

"I think I learned then that I don't know them, and should actually consider that in my class they can buy stickers by the kilogram. Why then should they pay attention to the ugly stickers that I brought? I have to bring something that challenges them."

Oren's diary sheds a strong light on how important it is to know the pupils' cultural world, and how integral that world is to teaching them.

“I felt that a layer of my pupils' personality was being revealed that I hadn't seen before. I tried to calm them ... but they were not focused on me anymore. There were some bothersome elements in the situation, when suddenly I understood how little I knew them, how great a culture gap there was between us. I sensed that not knowing their world and their language, I lose the sense of familiarity and cooperation that are the foundation stones of my educational work.”

In her diary, Tova describes how the context of the specific class affect her educational experience while teaching arithmetic:

"I taught arithmetic using a box of numbered picture cards. Every group in turn takes a card with a number question and tries to solve it. Whichever group solves the most, wins. In most groups, it went well and served its teaching purpose. However, in one group the competition was the main thing, not the learning, which upset me. For some reason I promised a prize to the winner. The boys chose the cards and got angry when they did not win. In the end, two of them tied and they 'counted out' to see who would get the prize. I did not want to give the prize, a key ring, because I did not like the competitive spirit. But in the end I did."

These examples and other demonstrate how novices come to understand that context is an integral part of teaching. Such insights necessarily broaden their professional thinking and consequently make for greater flexibility in their activities in the classroom, and outside it.

\subsection{Teaching Complexity: It Is a Multifaceted Job}

While entering into teaching, novices realize that being in class by their one means that they have to be involved with many duties at the same time. They become aware to the multifaceted nature of the profession. All the no- 
vices describe in their diaries the complexity characteristic of teaching, meaning that teaching is not a sum of single actions but a complexity in which each portion derived and connected to the other parts. The notion that teaching is involved with several attached actions at the same time assume to be as a kind of surprise for the novices:

"Already in the second day it become clear. Teaching is not a collection of separate actions. As a student teacher, I was used to occupy myself each time with a distinct aspect of teaching. Reality crouched this view. Suddenly I have to do at the same time several things. To teach was not only one mission. I had simultaneously to explain the new material, get pupils' attention, watch their reactions, while being patient, attentive, sharp-tongued and sharp-eyes. It was a kind of impossible mission. So difficult, so hard.” (Tamar)

"Suddenly I understood what it means. It was a prompt adjustment. Teaching become a whole entity construct from many details. It was so complex. It was difficult to decide where to start, where to invest my efforts. I realize that if I am starting to teach the lesson's content without paying attention to the management of the class I cannot progress with the lesson, but starting to manage the class took the class time. Therefore, I had to watch carefully my actions, calculate my professional steps. I might know it before, but now in class it become clear that every move has its own consequences. Then, I started to understand that teaching, as a profession, is not so simple.” (Rachel)

Anat pays a lot of attention to this characteristic in her diary. At her first report, she writes:

"I found myself thinking about teaching as a complex of connections and links. I had to map my planning. I remember that few months ago when I was a student teacher I thought about links concerning the lesson's sequence. That was the main connection that I saw. Now I understand that teaching is a kind of network, even a maze in which every teacher has both — to integrate and to unravel.”

Two months afterward, she started to describe how she is trying to cope with teaching complexity:

As a result of my understanding I stated to think about new ways which will help me to simplify the complexity of my teaching. I started this week to write all the actions that I have to make before teaching, while teaching and even after teaching. I made a kind of network with all the necessary actions. The complexity of teaching before thing was not as simple as I thought before. I realize that good planning is not enough. Working on my teaching network, as hard as it is seems to be a good start, I shall keep thinking about it, and probably I shall write it in the future.

As she assumed, the notion that teaching is a complex issue became as a concern. She tried to find alternative ways to handle this concern such as making notes or keeping daily routines. She did progress in her efforts. In addition, in her last report she wrote.

"Now, coming to the end of the year, I know that teaching complexity is a significant characteristic of teaching. There are no magic solutions. You just have to understand that teaching means thinking about many attached entities, and acting according to their complexity. Now that I know that this is an inseparable issue, I am thinking positively about this characteristic. Moreover, when I found myself succeed in doing several thing simultaneously I try to find what helped me do so.” (Anat)

From the above descriptions, it become clear that novices identify the complexity of teaching as an essential characteristic of teaching. Knowing that-fostering novices to find the parts of that complexity and learning how to manage between all of those elements—can help them to see their teaching work as a whole.

\subsection{Pluralism in Teaching}

From the descriptions of practice in teaching it was mentioned, in most of the diaries, that teaching is characterized according to its pluralism. The meaning of this characteristic directed to the notion that the teaching profession allows for and even demands a choice of open alternatives. Yael's diary records how she learned about that:

"Today I learned something new about teaching ... I saw I had to add to all the techniques and routines I'd acquired in the last month. I found myself looking for new teaching methods, additional solutions and 
thinking modes—-several times a day! I learned that I had to steer about and act in different directions, that there was no one single way, that only a broad and varied reserve could help me in my work."

Dana, stressing the need to choose among alternatives writes:

"As a student I thought there was a collection of techniques I had to learn. When I became a teacher, I found that the collection was just a collection. I understood that methods are not the essential thing. The essential thing is to know how to choose the most suitable among them ... The hardest thing was to select and to adapt."

In all the diaries, new teachers described how they found themselves in situations demanding a choice among alternatives, how they grow professionally from these experiences and how they learn to adapt to-or compromise with the limitations of the alternatives. Choosing alternatives and opening the door to varied solutions becomes a useful tool. Moreover, emerging educational insights and the heavy responsibility of making decisions are a challenging innovation for those entering the profession.

\section{Insights and Practical Implications}

The findings of the present research open the door to novices' understanding of the teaching world, as they cope with entry into the profession, and their first exposure to the real world of teaching.

Research's findings point toward a profile of teaching's characteristics in five dimensions: experiential, uniqueness to each practitioner, contextual vis-à-vis situation and environment, complexity, and pluralistic. Regarding those characteristics, all novices stressed that each one of them plays as a "lighthouse"; while starting to teach.

Novices' descriptions illustrate their ability to combine theoretical knowledge acquired in the pre-service training with contextual knowledge acquired in the course of entering the profession. Tying theory and practice together hints towards novices' professional growth—already in their first steps in teaching — stage, in which they examine their activities, identify needs for professional development and become responsible for them (Vonk, 1993), emphasizing and integrating between the multiple aspects of teaching (Moore-Russo \& Wilsey, 2014).

Identifying the experimental characteristic of teaching has a practical meaning since knowledge that comes from experience can help novices to become more flexible and better able to make analytical plans that build on this new awareness (Berliner, 1988). This characteristic of teaching is additionally refers to recent literature calling teacher education towards a more coherent illustration of the "clinical" characteristic of teacher education (National Council for Accreditation of Teacher Education, 2010).

The uniqueness of teaching, described by novices as an essential characteristic of teaching is described in literature's findings indicating that the characteristics and competencies of individual teachers, the features of the specific class and their interaction may play a significant role in the process of teaching and its outcomes (OECD, 2009).

Furthermore, novices also sense the force of actual practice as an integral part of learning how to teach. The research findings reveal ability to reflect on their work through an internal mirror, and, using it, to sketch the changing complexity of teaching (from teacher to teacher, from class to class and from lesson to lesson). That mirror illuminates matters of content, teaching processes, weighing opinion, thought patterns, and the coping strategies typical of the first year of work in education, all of which constitute a credible reflection of the teaching world.

The present study shows a great capacity on the part of how novices think and reflect on professional matters. The research's finding illustrates how novices—at the beginning of their careers—describe an accurate picture of the teaching's charactaristics.

Finding regarding the complexity of teaching are in line with previous literature indicating that teaching complexity is characterized by unpredictability, and multidimensionality (e.g. Clandinin, 1986; Doyle, 2006); and that the complexity of teaching is an additional characteristic of the profession (Darling-Hammond, 1999), a far more complex career than novices realize (Cookson, 2005; Murshidi, Konting, Elias, \& Fooi, 2006).

Identifying teaching complexity as an essential characteristic of the teaching profession should guide teacher educators in empowering novices and teachers with greater understanding of the complexity of learning rather than controlled with simplistic methods and instant recipes and routines for teaching (Darling-Hammond, 1999). 
Furthermore, understanding the complexity of their work should help them evaluate and adapt to various situations, as veterans often do (Berliner, 1988).

The implications derived from this study suggest that challenging of teaching novices is able to characterize the profession including its nature, complexity and demands.

The unique knowledge about teaching, that novices obtain during their first steps in the teaching world foster them to adapt survival skills necessary to meet the demands of the teaching profession.

The difficulties in starting to teach, and data about teachers who leave the system during their first working years (Allen, 2005; Darling \& Hammond, 1990; Goddard and Goddard, 2006; Ingersoll \& Smith, 2003) are generally and widely familiar. Hence an ongoing reflective dialogue with applicants during their academic training and at the stage of entry into the profession is recommended. It is likely to provide a channel of communication and activity that improves and advances professional training methods, along with the professional development of new teachers.

\section{References}

Allen, M. B. (2005). Eight Questions on Teacher Recruitment and Retention: What Does the Research Say? The Education Commission of the States (ECS). http://files.eric.ed.gov/fulltext/ED489332.pdf

Anhorn, R. (2008). The Profession That Eats Its Young. Delta Kappa Gamma Bulletin, 74, 15-26.

Berliner, D. C. (1988). The Development of Expertise in Pedagogy. Charles W. Hunt Memorial Lecture Presented at the Annual Meeting of the American Association of Colleges for Teacher Education. New Orleans.

Britzman, D. (1991). Practice Makes Practice: A Critical Study of Learning to Teach. Albany, NY: State University of New York Press.

Bullough Jr., R. V., \& Draper, R. J. (2004). Mentoring and Emotions. Journal of Education for Teaching, 30, 271-288. http://dx.doi.org/10.1080/0260747042000309493

Clandinin, D. J. (1986). Classroom Practice: Teacher Images in Action. Bristol, PA: Falmer Press.

Cochran-Smith, M. (2004a). Stayers, Leavers, Lovers, and Dreamers: Insights about Teacher Retention. Journal of Teacher Education, 55, 387-392. http://dx.doi.org/10.1177/0022487104270188

Cochran-Smith, M. (2004b). Walking the Road: Race, Diversity and Social Justice in Teacher Education. New York: Teachers College Press.

Connelly, F. M., \& Clandinin, D. J. (1988). Teachers as Curriculum Planners-Narratives of Experience. New York: The Ontario Institute for Studies in Education and Teachers, Columbia University.

Cookson, P. W. (2005). Your First-Year: Why Teach? Teaching Pre K-8, 36, 14-21.

Culross, J. (2007). Why I Teach. College Teaching, 52, 63-80. http://dx.doi.org/10.3200/CTCH.52.2.63-80

Darling-Hammond, L. (1999). Professional Development for Teachers: Setting the Stage for Learning from Teaching. Santa Cruz, CA: The Center for the Future of Teaching \& Learning.

http://www.cftl.org/documents/Darling_Hammond_paper.pdf

Darling-Hammond, L. (1990). Teachers and Teaching: Signs of a Changing Profession. In R. Houston (Ed.), Handbook of Research on Teacher Education (pp. 267-289). New York: Macmillan Publishing Company.

Doyle, W. (2006). Ecological Approaches to Classroom Management. In C. Evertson, \& C. Weinstein (Eds.), Handbook of Classroom Management: Research, Practice and Contemporary Issue (pp. 97-125). US: Lawrence Erlbaum Associa.

Fokkens-Bruinsma, M., \& Canrinus, E. T. (2012). The Factors Influencing Teaching (FIT)-Choice Scale in a Dutch Teacher Education Program, Asia-Pacific Journal of Teacher Education, 40, 249-269. http://dx.doi.org/10.1080/1359866X.2012.700043

Gilar, R., Ruiz, M., \& Castejón, C. L. (2007). Diary-Based Strategy Assessment and Its Relationship to Performance in a Group of Trainee Teachers. Teaching and Teacher Education, 23, 1334-1344. http://dx.doi.org/10.1016/j.tate.2006.07.012

Goddard, R., \& Goddard, M. (2006). Beginning Teacher Burnout in Queensland Schools: Associations with Serious Intentions to Leave. The Australian Educational Researcher, 33, 61-75. http://dx.doi.org/10.1007/BF03216834

Ingersoll, R. M., \& Smith, T. M., (2003). The Wrong Solution to the Teacher Shortage. Educational Leadership, 60, 30-33.

Ingersoll, R., \& Kralik, J. (2004). The Impact of Mentoring on Teacher Retention: What the Research Says. Denver, CO: The Education Commission of the States.

Inman, D., \& Marlow, L. (2004). Teacher Retention: Why Do Beginning Teachers Remain in the Profession? Education, 124, 605-614.

Kelchtermans, G., \& Ballet, K. (2002). The Micropolitics of Teacher Induction: A Narrative-Biographical Study on Teacher 
Socialization. Teaching and Teacher Education, 18, 105-120. http://dx.doi.org/10.1016/S0742-051X(01)00053-1

Kitching, K., Morgan, M., \& O’Leary, M. (2009). It’s the Little Things: Exploring the Importance of Commonplace Events for Early-Career Teachers' Motivation. Teachers and Teaching: Theory and Practice, 15, 43-58. http://dx.doi.org/10.1080/13540600802661311

Kyriacou, C., \& Kune, R. (2007). Beginning Teachers’ Expectations of Teaching. Teaching and Teacher Education, 23, 1246-1257.http://dx.doi.org/10.1016/j.tate.2006.06.002

Lortie, D. (1975). Schoolteacher: A Sociological Study. Chicago, IL: University of Chicago Press.

Mäkinen, M. (2013). Becoming Engaged in Inclusive Practices: Narrative Reflections on Teaching as Descriptors of Teachers' Work Engagement. Teaching and Teacher Education, 35, 51-61. http://dx.doi.org/10.1016/j.tate.2013.05.005

Maskit, D. (2013). First Months in Teaching-Novices Relate to Their Difficulties. Creative Education, 4, 1-8.

Maskit, D., \& Dickman, N. (2006). From “Student-Teacher” to "Becoming a Teacher”-Story of a Beginning. In A. Kupperberg, \& O. Olstein (Eds.), Discourse in Education (pp. 21-49). Tel Aviv: Klil Education Books with MOFET Institute.

Melnick, S. A., \& Meister, D. G. (2008). A Comparison of Beginning and Experienced Teachers' Concerns. Educational Research Quarterly, 31, 39-56.

Ministry of Education (2004). Policy Document. Jerusalem. (In Hebrew).

Moore-Russo, D. A., \& Wilsey, J. N. (2014). Delving into the Meaning of Productive Reflection: A Study of Future Teachers' Reflections on Representations of Teaching. Teaching and Teacher Education, 37, 76-90. http://dx.doi.org/10.1016/j.tate.2013.10.002

Murshidi, R., Konting, M. M., Elias, H., \& Fooi, F. S. (2006). Sense of Efficacy among Beginning Teachers in Sarawak. Teaching Education, 17, 265-275. http://dx.doi.org/10.1080/10476210600849730

National Council for Accreditation of Teacher Education, NCATE (2010). Report of the Blue Ribbon Panel on Transforming Teacher Education through Clinical Practice: A National Strategy to Prepare Effective Teachers: Report of the Blue Ribbon Panel on Clinical Preparation and Partnerships. Washington DC. http://www.ncate.org/LinkClick.aspx?fileticket=zzeiB1OoqPk\%3D\&tabid=715

Norman, P. J., \& Feinman-Nemser, S. (2005). Mind Activity in Teaching and Mentoring. Teaching and Teacher Education, 21, 679-697. http://dx.doi.org/10.1016/j.tate.2005.05.006

OECD (2009). Creating Effective Teaching and Learning Environments: First Results from TALIS. http://www.oecd.org/berlin/43541655.pdf

Patton, M. Q. (2002) Qualitative Research and Evaluation Methods (3rd ed.). Thousand Oaks, CA: Sage Publications.

Stoeber, J., \& Rennert, D. (2008). Perfectionism in School Teachers: Relations with Stress Appraisals, Coping Styles, and Burnout. Anxiety, Stress and Coping, 21, 37-53. http://dx.doi.org/10.1080/10615800701742461

Stoughton, E. H. (2007). “How Will I Get Them to Behave?” Pre Service Teachers Reflect on Classroom Management. Teaching and Teacher Education, 23, 1024-1037. http://dx.doi.org/10.1016/j.tate.2006.05.001

Strauss, A. L. (1987). Qualitative Analysis for Social Scientists. Cambridge: Cambridge University Press. http://dx.doi.org/10.1017/CBO9780511557842

Strauss, A., \& Corbin, J. (1994). Grounded Theory Methodology: An Overview. In N. K. Denzin, \& Y. S. Lincoln (Eds.), Handbook of Qualitative Research (Charpter 17, pp. 273-285). Thousand Oaks, CA: SAGE.

Vonk, J. H. C. (1993). Mentoring Beginning Teachers: Mentor Knowledge and Skills. Mentoring and Tutoring: Partnership and Learning, 1, 31-41. http://dx.doi.org/10.1080/0968465930010106

Weinstein, C. S. (1990). Prospective Elementary Teachers’ Beliefs about Teaching: Implications for Teacher Education. Teaching and Teacher Education, 6, 279-290. http://dx.doi.org/10.1016/0742-051X(90)90019-2 
Scientific Research Publishing (SCIRP) is one of the largest Open Access journal publishers. It is currently publishing more than 200 open access, online, peer-reviewed journals covering a wide range of academic disciplines. SCIRP serves the worldwide academic communities and contributes to the progress and application of science with its publication.

Other selected journals from SCIRP are listed as below. Submit your manuscript to us via either submit@scirp.org or Online Submission Portal.
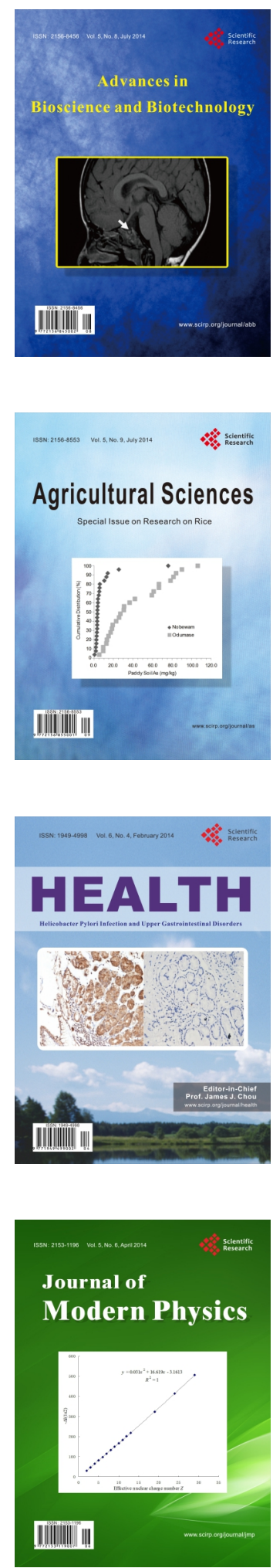
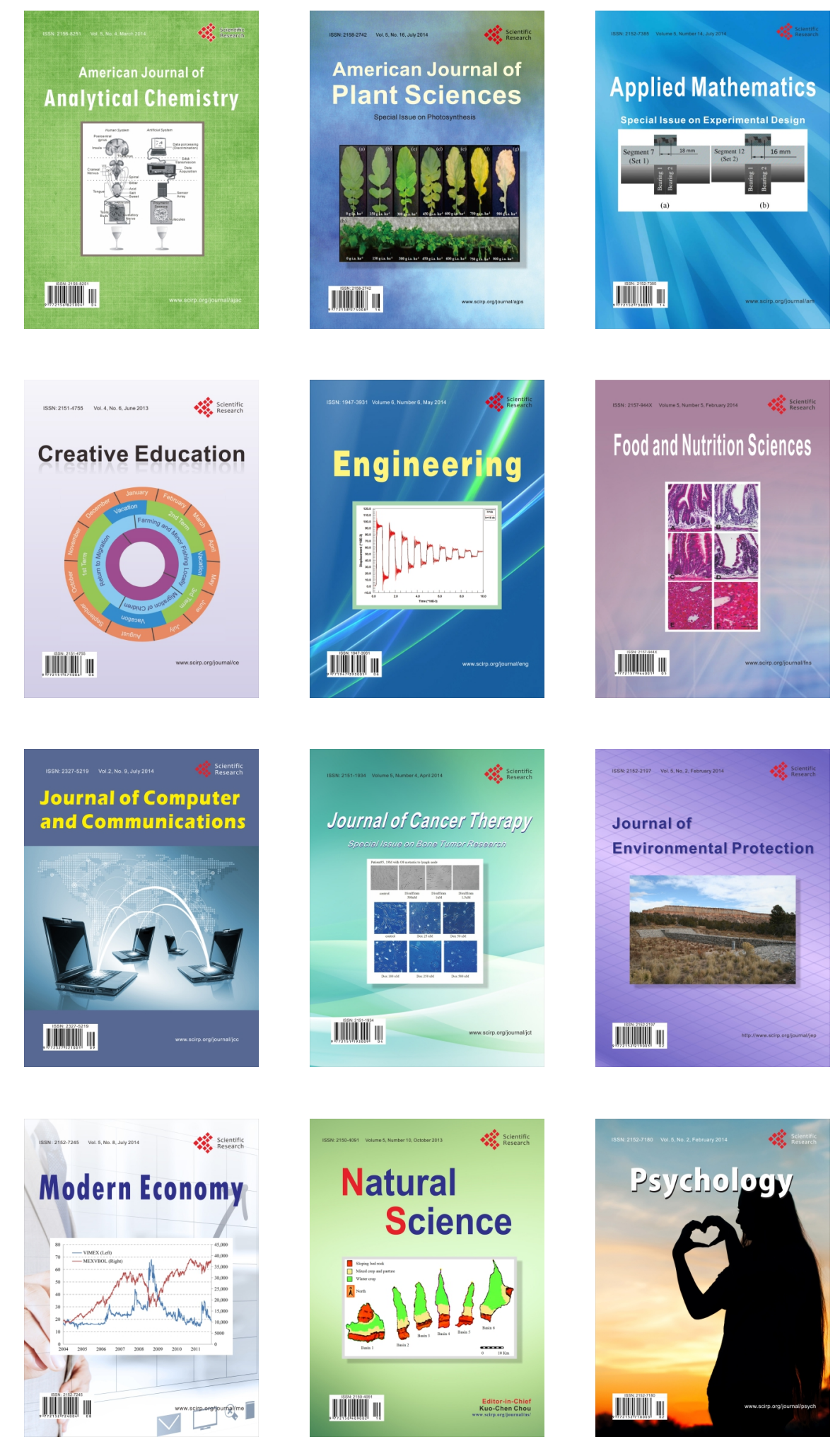